\title{
PERMANÊNCIA DO TEOLÓGICO-POLÍTICO? - UMA ANÁLISE DO PENSAMENTO POLÍTICO DO MATERIALISMO ATEU DE HOLBACH A PARTIR DE CLAUDE LEFORT
}

\author{
Arthur Roberto Capella Giannattasio*
}

\begin{abstract}
Resumo: A partir da análise do fundamento do Político proposto em algumas obras do Barão de HOLBACH, este artigo visa a examinar a possibilidade de o modo como o materialismo ateu do século XVIII compreende o fundamento da Lei e do Político pode apontar para uma organização social de caráter político ou teológico-político, conforme a chave de leitura fornecida por C. LEFORT. Após a exposição da diferença entre o Político e o Teológico-Político e da breve análise da concepção de Política Natural do Barão de HOLBACH (fundamento do social, da Moral, da virtude e das Leis e o fundamento e os limites naturais da instituição política do Governo), é possível constatar a persistência do teológicopolítico também na concepção materialista do século XVIII. Essa condição deriva da singela substituição de Deus pela Natureza (transcendência) no exercício da função simbólica de preencher intemporalmente o lugar do Poder político.
\end{abstract}

Palavras-chave: Político; Teológico-Político; Fundamento das Leis; Fundamento do Poder; materialismo ateu

\section{Introdução ${ }^{1}$}

A partir da análise do fundamento do Político proposto em algumas obras do Barão de HOLBACH, este trabalho visa a examinar a possibilidade de o modo como o materialismo ateu do século XVIII compreendia o fundamento da Lei e do Político pode apontar para uma organização social de caráter político ou teológico-político, conforme a chave de leitura fornecida por C. LEFORT (Lefort 14).

A juridicidade atribui o caráter de jurídico a determinadas normas sociais de conduta. É importante compreender a definição de critérios específicos aptos a estabelecer a concessão desse revestimento de normas sociais de conduta por uma aura de exigibilidade, de obrigatoriedade e de vinculação. A qualificação dada pela específica condição de "jurídico" exclui série de outras normas que não partilham dessa mesma consideração social. A atribuição dessa qualidade depende da maneira pela qual cada sociedade percebe o fenômeno jurídico, ou melhor, está em função daquilo que um corpo social sente ser o fundamento de uma condição jurídica.

Aço ou cristal; mão fechada ou mão aberta. Voluntas versus Ratio. Milenarmente se discute o que seja o direito e qual o modo de o conhecer. Na essência as duas posições se contrapõem, às quais todas as imensas variantes se podem reconduzir ou das quais, por nexos

\footnotetext{
* Doutor em Direito pelo Departamento de Direito Internacional e Comparado da Faculdade de Direito da Universidade de São Paulo - Largo São Francisco (FDUSP). Pesquisador da Escola de Direito de São Paulo da Fundação Getulio Vargas (DIREITO GV); Ex-bolsista da CAPES - Proc. n. BEX 0304/11-5.
} 
mais ou menos directos, todas derivam. De acordo com uma delas o direito corresponde a uma ordem objectiva, racional, transcendente. Configura-o outra como um produto essencialmente voluntário e imanente. Ambas com manifestações na Idade Clássica, ambas encontraram na Idade Média momentos epigonais. Tão perto de nós tudo isto está - que tudo isso ainda nos comanda. O tempo não é senão uma ficção. (Albuquerque 1, p. 752).

A citação precedente se refere a um debate periodicamente retomado no pensamento da Filosofia Política, a ser resumido nos seguintes termos: qual seria, a final, o fundamento da Lei: a razão ou a vontade? A variabilidade histórica da resposta permitiria entender não apenas os critérios de atribuição de juridicidade a normas sociais de condutas, mas também, principalmente, a maneira pela qual cada uma das sociedades se compreendeu ético-politicamente em seu tempo e espaço. Nesse sentido, durante a experiência jurídico-política da Revolução Francesa também houve a manifestação do embate clássico entre razão e vontade como fundamento da Lei.

Naquele período, o problema sobre o fundamento da Lei se instaurou em torno do conflito entre as duas dimensões mencionadas. Haveria o conflito entre a Razão, concebida como natural e laicizada, orientada misticamente conforme uma visão pedagógico-teológica do mundo (Fauchet 6) herdeira de uma tradição maçônica (Nascimento 15 e 17, p. 26), e o fenômeno volitivo, rearticulado politicamente em torno da ideia de Povo, detentor da nem sempre pacífica e adequadamente compreendida vontade geral soberana (Althusser 2; Cardoso 4; Fortes 7 e 8; Lebrun 13; Nascimento 16; Rousseau 19).

Todavia, há que se notar a existência de uma linha de pensamento em segundo plano sobre o fundamento do Político e das Leis que também se manifestou em diversos círculos sociais da intelectualidade das Luzes Francesas. Trata-se do pensamento do Iluminismo que no século XVIII revitalizou parcela do materialismo clássico à luz da contribuição da reflexão crítica de Espinosa sobre a apropriação do discurso religioso pelo Estado. O objetivo dessa vertente iluminista consistia em combater a justificativa teológica do Governo de déspotas e ficou conhecida como materialismo ateu.

Sustentados na crítica teológico-política de Espinosa, filósofos que partilhavam das ideias materialistas no início das Luzes Francesas pensaram e propuseram temas da Filosofia Política, como o fundamento do Político, da Moral e das Leis sob a influência da perspectiva materialista revigorada enquanto manifestação do natural. O objetivo 
consistia em criticar o fundamento religioso-cristão do Poder político e, com isso, afastar a permanência de um fundamento teológico-político do Poder.

No entanto, é possível indagar se o Projeto da crítica do fundamento teológicopolítico do Poder por parte do materialismo ateu deteria a aptidão de obstar, de maneira efetiva, a perpetuação do teológico-político, ou seja, se sua argumentação sinalizava para a instauração de uma ordem social organizada exclusivamente em torno de um critério puramente político.

Em outros termos, é possível inquirir se a proposta desenvolvida pelos autores materialistas do Iluminismo francês apresentaria um fundamento político do Poder, ou se ela simplesmente substituiria um mecanismo de teológico-político por outro. É este aspecto que o presente estudo pretende examinar, com o objetivo de aprimorar a compreensão do materialismo ateu do século XVIII, a partir de escritos do Barão de HOLBACH que retratam sua proposta da Política Natural.

O presente texto está dividido em três partes fundamentais. A primeira apresenta sucintamente a diferença entre uma organização social política e outra teológicopolítica, de acordo com as características explicitadas por C. LEFORT (Lefort 14). Em seguida, serão desenvolvidas considerações pontuais acerca da Política Natural de HOLBACH, com o objetivo de precisar sua proposta de fundamento do Político. Em terceiro lugar, será exposta uma avaliação do Projeto de HOLBACH, com o objetivo de aferir o caráter político ou teológico-político do mesmo.

Espera-se, deste modo, que se possa contribuir minimamente para o aprimoramento da compreensão do pensamento político desenvolvido pelo movimento do materialismo ateu do século XVIII, a fím de permitir a ampliação do círculo de discussões sobre o tema do fundamento do Poder político e das Leis.

\section{A Organização Política e a Organização Teológico-Política}

O tema do fundamento da Lei remonta à concepção da organização da sociedade - passível de ser distinta em política ou teológico-política, discussão relacionada aos debates jusfilosofico-políticos nas Luzes Francesas. Teria havido na Modernidade uma separação entre os âmbitos da Política e da Religião, tendo sido a primeira restringida ao domínio das questões do Estado, enquanto que a última teria se cingido à esfera privada. Com essa distinção, a Política teria se laicizado, restando isolada da Religião (Lefort 14, p. 250). 
No entanto, se é certo que "as instituições políticas se cindiram há muito tempo das instituições religiosas" (Lefort 14, p. 251), é possível indagar se a organização social "conserv[a o religioso] sob os traços de novas crenças, novas representações, de tal modo que [ele] possa retornar à superfície, sob formas tradicionais ou inéditas" (Lefort 14, p. 251). Afinal, se "os homens, durante séculos ou talvez milênios [ignoraram] essa separação, [e conferiram] uma expressão religiosa às funções exercidas pelo poder ou às relações de força de onde o poder surgi[ra]" (Lefort 14, p. 258), talvez seja possível encontrar uma reminiscência dessa indistinção teológicopolítica no materialismo ateu de $\mathrm{HOLBACH}$, inclusive no que se refere ao fundamento da Lei e ao princípio de organização social.

Por isso mesmo, é importante apresentar brevemente as formas de organização social características de uma sociedade organizada política ou teológico-politicamente, pois isso poderá auxiliar na melhor compreensão do problema sobre o fundamento das Leis. Assim, serão examinados em que medida um ou outro fundamento do Direito pode refletir uma concepção de organização social política ou teológico-política e as implicações dessa diferença de princípio político organizacional de uma sociedade.

O Político é entendido como o princípio gerador de toda sociedade, ou ainda, das diversas formas de sociedade (Lefort 14, p. 253), de maneira que cada sociedade possui sua forma de organização política apresentada de uma determinada maneira específica, conforme sua Constituição. Isso significa que a organização política do social é produzida de acordo com a identidade própria de cada social, exatamente porque "uma sociedade se distingue de outra por seu regime, ou diremos melhor, já que a palavra se desgastou: por uma certa mise en forme da coexistência humana." (Lefort 14, p. 254, grifos do autor).

A Política existe em toda e qualquer sociedade, não havendo sociedade apolítica, pois a própria noção de sociedade aponta para uma necessária referência ao elemento político dentro de si, "a um modo [singular] de instituição do social [que articula suas dimensões e as relações que se estabelecem em seu bojo entre classes, grupos, indivíduos, assim como entre práticas, crenças, representações].” (Lefort 14, p. 254).

O fenômeno político e o fenômeno religioso remetem à noção de símbolo, ou seja, à ideia de que um e outro mediam a apresentação do mundo para o Homem de acordo com suas específicas determinações de sentido. Em outras palavras, ambos “comandam, por meio de suas próprias articulações, um acesso ao mundo" (Lefort 14, p. 258-9), razão pela qual não se pode ignorar a possibilidade de entrechoque entre cada 
uma das perspectivas em toda sociedade, pois ambas disputariam a exclusividade da arena de possíveis mediações significativas do real para o Homem.

Essa distinção e esse embate se manifestam na conformação da mise en forme de cada uma das organizações políticas da sociedade em razão do preenchimento que cada um deles faz do lugar do Poder. A localização do Poder é constituída pela primeira divisão da sociedade, a qual faz surgir o fenômeno do Poder - detido por uns sobre os outros (relação mando-obediência).

Essa divisão que constitui o espaço da sociedade determina a diferenciação entre o lugar da sociedade e o lugar do Poder, estabelecendo uma relação de interioridadeexterioridade. O Poder se localizaria fora da sociedade, em um lugar "a partir do qual ele se deixa ver, ler, nomear" (Lefort 14, p. 262). Diante desse polo simbólico externo à sociedade, esta se conhece e se reconhece como tal: "ser[ia] melhor dizer que o poder dá sinais de um fora, a partir do qual a sociedade se define." (Lefort 14, p. 262, grifos do autor). Isto assegura ao grupo social uma imagem de si mesmo e a compreensão de seus espaços e de seus limites (Lefort 14, p. 263).

A divisão social fundamental (porque fundante) constitui o Poder e a sociedade como entidades diversas que se excluem, mas que mutuamente se exigem. Pelo reconhecimento do Poder, a sociedade se constitui e se unifica como tal, entendendo-se a si mesma como o local que não é o Poder. Por sua vez, exterior à sociedade, o Poder não poderia se encontrar em algum lugar real da sociedade, porque para esta não faria sentido se deste modo fosse (Lefort 14, p. 262).

Sob todas suas formas, sempre é para o mesmo enigma que o poder remete: enigma de uma articulação entre interior-exterior, de uma divisão instituindo um espaço comum, de uma ruptura que simultaneamente é um relacionamento, de um movimento de exteriorização do social que vai de par com um movimento de interiorização do social. (Lefort 14, p. 262).

Os regimes políticos detêm uma conformação estrutural bastante singular da sociedade naquilo que se refere à determinação do lugar do Poder. O Poder se mostra como um lugar vazio, ou seja, como um lugar de propriedade de ninguém, sendo apenas temporariamente ocupado por alguém escolhido e alternado periodicamente pela sociedade: os Homens estão proibidos de se apropriar do Poder (Lefort 14, p. 262). 
A forma política mantém o Poder "separado do simbólico e do real [...] em virtude de um discurso que faz sobressair que o poder não pertence a ninguém; quem o exerce não o detém, melhor: não o encarna." (Lefort 14, p. 262). Apenas por meio de uma periódica competição entre candidatos temporários ao lugar do Poder a autoridade se faz e se refaz na sociedade (Lefort 14, p. 262); afinal, nos regimes políticos, os atores políticos reconhecem a impossibilidade mútua e recíproca de cada um deles se apossar do Poder: recusa-se que qualquer um ocupe o lugar do Poder definitivamente, pois se evita que alguém seja o Poder.

[S]ua virtude está em levar a sociedade à prova de sua instituição; lá onde se perfila um lugar vazio, não existe conjunção possível entre o poder, a lei e o saber [...]; o ser do social [...] se dá sob a forma de um questionamento interminável (do qual dá testemunho o debate ininterrupto, movediço, das ideologias). (Lefort 14, p. 265).

Se o Poder não pertence a ninguém, em um primeiro momento isso significa que ele "não pertence a ninguém d'entre nós" (Lefort 14, p. 263). Mas, além disso, isso também quer dizer que ele igualmente não cabe a qualquer entidade transcendente ao Homem. Ninguém, ou ainda, nenhuma espécie metafísica de ser - como mineral, vegetal, animal, Homem, anjos ou Deus, para lembrar a hierarquização tipicamente tomista (Aquino 3) - pré-determina o sentido da sociedade, porque é ela que se lhe atribui esse sentido. Em outras palavras, ninguém ocupa de antemão o espaço do Poder em um regime político: respectivamente, nem Um (Homem), nem Outro (outro ser da hierarquia metafísica de seres), pode ser o Poder político, nem o fundamento das Leis (Lefort 14, p. 263).

A periódica reposição de Homens para que ocupem temporariamente o lugar do Poder exige uma institucionalização de conflito social regrada e a ser cumprida por aqueles que competem pelo lugar do Poder. Este procedimento competitivo retarda mas nem sempre impede - a construção da "ilusão de um grande indivíduo, cuja vontade cada qual deverá reconhecer como sua" (Lefort 14, p. 268), que invariavelmente tende a se encaminhar para a degeneração completa derivada da ascensão do tirano.

O despotismo, elevando aos poucos sua horrenda cabeça e devorando tudo o que percebesse de bom e de sadio em todas as partes do Estado, conseguiria por fim esmagar sob seus pés as leis e o povo, e estabelecer-se sobre as ruínas da república[;] tudo seria devorado pelo 
monstro e os povos não mais teriam nem chefes, nem leis, mas unicamente tiranos. Desde esse momento também deixariam de interessar os costumes e a virtude, pois em todo lugar onde reina o despotismo, cui ex honesto nulla est spes, não suporta ele qualquer outro senhor; desde que fale, não há probidade nem dever a consultar, e a única virtude que resta aos escravos é a mais cega obediência. (Rousseau 18, p. 279-80).

Apesar de quase apontar para a dissolução das relações sociais, o conflito institucionalizado não está à disposição do Poder. Na verdade, o Poder depende da existência do conflito para ser ocupado de maneira reputada política e democraticamente legítima, ou ainda, para que ele e seu Direito se apresentem como detendo fundamento efetivamente político (Lefort 14, p. 264) 2 .

São dois fenômenos igualmente significativos da articulação que mencionávamos entre a ideia de poder como pura instância simbólica e a ideia de uma sociedade como sendo isenta de uma unidade substancial. [... A] atividade propriamente política te[m] por efeito instituir uma cena na qual o conflito se representa aos olhos de todos [...] como necessário, irredutível, legítimo. [... O] antagonismo dá credibilidade a uma outra vocação: a da sociedade para a divisão. (Lefort 14, p. 264, grifos do autor).

O preenchimento do lugar do Poder é, no entanto, diverso nos regimes cuja mise en forme é teológico-política. Nestes, o lugar do Poder não é um lugar vazio, pois está ocupado por alguma entidade que incorpora o Poder e que se identifica com ele - ou simplesmente, que é o Poder. A sociedade é composta por indivíduos considerados como "sujeitos [ao Poder] pelo próprio fato de serem membros." (Lefort 14, p. 263). O Poder é ocupado por "deuses, [pela] Cidade e [pela] terra santa” (Lefort 14, p. 263).

Neste caso, o Poder é encarnado por alguma entidade expressa pelo Homem que, uma vez dele emanada, é mantida na transcendência e é reconhecida como tendo recebido a exclusividade de ocupação intemporal do lugar do Poder pelos próprios Homens. Uma vez expressa pelo Homem, esta entidade se exterioriza e se cristaliza como um Outro ao Homem, voltando-se sobre este para, conforme sua medida de entidade Outra, orientar da exterioridade e de maneira rígida e uniformizante o Homem.

O fundamento religioso do poder se encontra plenamente afirmado, assim, ele surge como o guardião e o fiador da certeza que sustenta a experiência do mundo e, ao mesmo tempo, surge como o detentor da 
lei que se imprime nas relações sociais e as mantém unidas. (Lefort 14 , p. 265-6).

O fundamento do Poder e das Leis é uma entidade externa ao Homem, um Outro que lhe significa o mundo de uma maneira transcendente - não completamente humana porque conforme a estrita limitação de perspectiva de uma criatura concebida (artifício humano) que adquirira contornos religiosos (Lefort 14, p. 265). O mundo, o Poder e o Direito se apresentam aos Homens como provenientes de uma origem Outra - a eles externa, transcendente, conforme o modo como este artefato lhes apresenta o mundo, o Poder e o Direito. Essa significação dada por entidade artificial que media o mundo para os Homens é captada e considerada religiosamente como o fundamento do Poder político e das Leis.

Dessa forma, por abolir a figura do Outro transcendente ao Homem como fundamento do Poder e do Direito, a organização política de uma sociedade mantém o Poder na "divisão em que é engendrado, e assim, ele permanece inapreensível (subtraído à apropriação e à representação)" (Lefort 14, p. 266), ao passo que, ao partir da potência unificadora externa ao Homem, a organização teológico-política apresenta um mediador não-humano como medida una e coerente de constituição do Poder e das Leis que asseguraria a unidade das relações sociais (Lefort 14, p. 265-6).

A organização política da sociedade constantemente afirma de maneira ininterrupta o fato político de haver a divisão social fundamental primeira entre Poder e sociedade, ou seja, entre mando-obediência, ao passo que a organização teológicopolítica eclipsa essa condição por seu princípio unificador transcendente ao Homem. Surgem neste caso um Poder e um Direito que se apresentam como potência transcendente, detentora de sua própria razão de ser, ou ainda, "que, na falta disso, não haveria nem permanência, nem coesão da sociedade e, nesse sentido, ele exige uma obediência incondicional, exige o apagamento do interesse privado diante do imperativo de sua conservação." (Lefort 14, p. 268).

Diante dessa breve exposição, é possível tentar compreender se a proposta sobre o princípio do político desenvolvida por HOLBACH pode fundamentar um princípio organizacional político ou teológico-político da sociedade. 


\section{A Proposta do Princípio do Político do Materialismo Ateu de Holbach}

Para o Barão de HOLBACH, o Político deteria um princípio natural que remontaria à natureza humana, de onde se poderia deduzir um Sistema Político de caráter natural. Essa peculiar condição revelaria que uma política saudável não seria sobrenatural, nem misteriosa, mas simples, desde que se seguissem os princípios políticos certos e seguros inscritos no registro da natureza do Homem, aceitos por meio da dissipação dos preconceitos e das noções falsas (Holbach 9, p. V; 12, p. V-VIII).

\footnotetext{
As paixões, os interesses imaginários de Príncipes, as ideias metafísicas da Teologia, as intrigas tenebrosas das cortes, contribuíram sobretudo para fazer da ciência do Governo um caos impenetrável para os espíritos, [...]. (Holbach 9, p. V-VI, tradução nossa).
}

Os princípios da Política seriam simples e evidentes (Holbach 9, p. 3), não se devendo se perder em noções abstratas e metafísicas. Por isso, um dos princípios verdadeiros da harmonia social que o Governo deveria estabelecer seria a máxima da Política Natural: "nenhum povo será feliz se ele não for governado segundo as Leis da Natureza, que sempre conduzem à virtude.” (Holbach 9, p. VII, tradução nossa).

Não se pode ignorar, inclusive, que para o mesmo autor sempre existiram sociedades e Governos, ou seja, sempre teria havido associações entre Homens - a começar pela família - e Homens governados - a começar pela submissão da família ao pai, o chefe reconhecido por seus membros por natureza.

A expansão numérica dos membros de uma família teria feito um pai o primeiro Rei (Holbach 9, p. 55-6). O Governo, as leis, a Política e o pacto social teriam sido constituídos para o único fim de atendimento da moral natural do Homem, ou ainda, para a observância da natureza humana (Holbach 11, p. 19) - por a Moral humana ser fundada sobre a Natureza e sobre suas necessidades, bem como sobre as vantagens naturais da vida social (Holbach 12, p. VIII).

Nos itens a seguir, examinar-se-ão o fundamento natural da sociedade e das normas morais e jurídicas (lei natural, lei civil e direito das gentes) e o fundamento e os limites naturais da instituição política do Governo. Essa análise permitirá evidenciar mais precisamente os termos segundo os quais o autor compreende o fundamento das 
Leis e do Poder político a partir de seu convite para se buscar na Natureza os remédios para os males criados pela imaginação do Homem (Holbach 12, p. VI).

\subsection{Fundamento Natural da Sociedade: Utilidade e Vantagem da Associação}

Segundo o Barão de HOLBACH, a sociabilidade seria natural e derivaria da inclinação humana para viver com os seres de sua espécie. Tratar-se-ia de um sentimento natural reforçado pelo hábito e cultivado pela razão: seria a "sociedade obra da Natureza, por ser a Natureza quem insere o Homem na Sociedade." (Holbach 9, p. 3, tradução nossa), inclusive porque o Homem seria obra da Natureza. Com efeito, para HOLBACH, o Homem somente existiria na Natureza, isto é, estaria submetido às leis dela e não poderia jamais dela se esquivar, nem em sociedade, nem em pensamento (Holbach 12, p. 1-2).

Como fruto da razão adviria o sentimento natural de amor da sociedade ou da sociabilidade, pois a experiência e a reflexão forneceriam o conhecimento daquilo que é útil ou inútil ao Homem. A razão mostraria que é na sociedade que o Homem poderia encontrar tudo o que necessita para se conservar e para se tornar feliz, de modo a preferir naturalmente o bem do prazer ao mal da dor (Holbach 9, p. 3-4; 10, p. 10).

Ele se torna razoável, ou seja, capaz de comparar as vantagens que a vida social lhe fornece com as desvantagens que ele experimentaria se estivesse privado da Sociedade. A partir dessas experiências, dessas reflexões, dessa comparação, ele prefere um estado que lhe garanta uma existência agradável e conforme a seu ser à solidão que o desagrada, que o deixa inquieto, que o deixaria desprovido de segurança. Em uma palavra, o homem é sociável porque ele aprecia o bem-estar e porque lhe agrada um estado de serenidade. (Holbach 9, $\mathrm{p}$ 4, tradução nossa).

Para o autor, todo Homem tende à felicidade, e a vida em sociedade lhe propõe a possibilidade de alcançar este objetivo. De fato, a associação entre Homens se constituiria em torno daquele objetivo, pois é para ser feliz que o Homem vive em sociedade. Esta seria simplesmente uma associação de Homens reunidos por seus interesses para agirem de modo concertado em direção à conservação e à felicidade comuns (Holbach 11, p. 4). 
Por isso, nada mais seria natural ao Homem do que visar à sociedade: ela derivaria em suma de seu desejo de busca da conservação e de uma existência feliz, ou seja, de um amor-próprio típico que orientaria a uma procura ardente pelos meios de sobreviver. Haveria vantagens naturais a uma vida social (Holbach 10, p. II) e a ausência de semelhantes tornaria o Homem um ser infeliz, pois o necessário apenas seria encontrável em vida social, à qual o hábito acostumaria (Holbach 9, p. 4-7).

Assim, para HOLBACH, um Estado natural prévio à sociedade seria impossível, pois o Homem não viveria jamais fora da sociedade, a começar pela sociedade celebrada entre um homem e uma mulher, progressivamente expandida para outros parentes, como irmãos e irmãs. Nada mais oposto à natureza pensar que o Homem viveu por algum momento isolado dos outros, sem qualquer espécie de relação ou de comunicação: todo estado do Homem é naturalmente social por, a final, a sociedade ser o produto típico da natureza do Homem (Holbach 9, p. 4-5 e 55; 10, p. II).

Nesse sentido, não se dissociariam Estado natural e Estado social, por sociedade ser natureza: em qualquer momento que se avaliasse, o Homem se encontraria no estado de Natureza (Holbach 10, p. II). Tal condição não desapareceria com a instauração da sociedade, por esta ser naturalmente necessária, sem se poder ignorar a sociabilidade natural do homem (Holbach 9, p. 27): o social é natural.

O homem governado por um Rei está tanto em um estado de Natureza, como um selvagem que vaga pelas florestas. Por mais que ele faça qualquer coisa, adote qualquer intuição, ou imagine qualquer meio para melhorar sua situação, ele não consegue nunca sair de sua natureza : ele está sempre sob as leis dela; ele está sempre igulamente forçado a segui-las; ele segue incessantemente em direção ao fim que essas leis lhe propõem. (Holbach 9, p. 27, tradução nossa).

Assim, o mais útil seria permanecer na condição natural de sociedade em que o Homem se encontra desde o nascimento, tendo em vista ser vantajosa para ele. Apenas em grupo não estaria privado de série de facilidades, como o corte de árvores ou a caça. É o interesse ou a necessidade que tornam o Homem sociável, e muito ele perderia se se afastasse dos demais, pois isso lhe traria um estado de miséria, de fraqueza e de infelicidade contrário à natureza de bem-viver com segurança e certeza, com força, com felicidade e sem medo (Holbach 9, p. 5-8). 
A felicidade humana em sociedade decorreria do fato de que todo Homem necessita da multiplicação inventiva das possibilidades de sensações corporais que impedem sua queda na languidez e no tédio - o que apenas ocorre com sua inserção no social. O Homem selvagem tem menores possibilidades de sensações do que nas sociedades policiadas, pois apenas nestas teria acesso a vantagens às quais por natureza deseja - o que não ocorreria se se mantivesse isolado (Holbach 9, p. 4, 7 e 9-10).

\subsection{Fundamento da Moral e das Leis (Natural, Civil e Direito das Gentes)}

Segundo essa perspectiva, tudo estaria ligado no mundo da moral da mesma maneira como ocorre no mundo físico (Holbach 10, p. I). Com efeito, o Homem seria por essência um ser físico, e a moralidade derivaria do ser físico percebido a partir de um ponto de vista (Holbach 12, p. 3). Em outros termos, os princípios da moral, da política, do Direito também estariam fundados na simplicidade clara da Natureza, da mesma maneira que o mundo físico. Isso implicaria reconhecer que a Moral que convém ao Homem é aquela fundada na Natureza do Homem (Holbach 10, p. 58 e 60).

Por isso, a Moral deve apreender adequadamente aquilo que é o Homem, o fim a que ele se propõe e os meios que ele procura para se realizar, ou seja, respectivamente: (i) um ser sensível que aprecia o prazer e que repudia a dor; (ii) um ser inteligente, por eleger um fim e por levantar os meios necessários para a ele chegar; e (iii) um ser racional, por optar segundo a experiência pelo melhor dentre os meios disponíveis. A partir dessa tripla condição legada naturalmente ao Homem, a Moral deve assegurar a busca da felicidade - a perduração do prazer e do bem-estar mais sólido, não devendo o atrapalhar na procura, mas o auxiliar e o encorajar nesta empreitada (Holbach 10, p. 59).

Deste modo, em primeiro lugar, para buscar a felicidade o Homem deve existir, razão pela qual ele procura meios que assegurem sua subsistência e se afasta de tudo aquilo que o possa prejudicar ou o atrapalhar. A convivência com os demais Homens que detêm os mesmos desejos e as mesmas aversões - é o meio natural mais imediato que permite a cada um fruir das vantagens de que necessita e evitar os males dos quais deve se afastar. A Moral natural revela, portanto, que para se assegurar a felicidade do Homem, este deve se associar a outros Homens, de modo que, pela ocupação com a felicidade dos outros, estes também se ocupem da felicidade dele (Holbach 10, p. 59).

Se há um fundamento natural do social, não seria diferente a origem das normas morais e jurídicas: de todos os seres, o mais necessário ao Homem é o próprio Homem 
(Holbach 10, p. 59). Apenas pelo estabelecimento do Estado natural de sociedade se asseguram as vantagens corporais e mentais dos Homens. Desta convivência surgem relações entre a sociedade e seus membros das quais derivam deveres recíprocos: se as partes devem ao seu todo, o todo também deve a suas partes (Holbach 9, p. 8).

A sociedade deve garantir a suas partes uma situação melhor do que elas se encontrariam se permanecessem isoladas: desejar a felicidade nada mais é que procurar um meio para a existência feliz e para o bem-estar (Holbach 10, p. 59). A sociedade deve às partes a possibilidade de bem viver, e o Homem não perde sua independência se não receber alguma contraprestação maior derivada diretamente da associação ${ }^{3}$, tendo em vista que se dará aos outros utilmente, e vice-versa (Holbach 9, p. 8-9).

Ressalte-se, nesse sentido, a particular figura do ateu virtuoso no pensamento moral de HOLBACH: seria possível valorizar determinadas condutas moralmente por estarem materialmente justificadas. Não haveria necessidade de referência a Deus ou a outra entidade, pois a Moral estaria fundada na própria Natureza do Homem de se relacionar com outros em sua associação. A obrigação moral consistiria precisamente na constatação de necessidade de ser útil para aqueles que se mostram necessários à nossa própria felicidade e em evitar aqueles que podem obstar a realização dela (Holbach 10, p. 71-3).

É muito natural que todo homem ame a si próprio, mas é contra a natureza de um ser sociável amar unicamente a si mesmo, pois os outros são indispensavelmente necessários à própria felicidade. Aquele que apenas ama a si mesmo não tem o direito de exigir a afeição de ninguém. (Holbach 10, p. 118, tradução nossa).

Deste modo, o interesse natural em se manter unido para assegurar os bens que por natureza o Homem deseja é o fundamento das virtudes sociais - e não qualquer divindade na qual se creia supersticiosamente (Holbach 10, p. 72-3). Este seria o verdadeiro motivo pelo qual o Homem realizaria tudo em nome de seus semelhantes (Holbach 9, p. 10): amar aos outros não significaria algo diferente do que amar os meios para viabilizar a conservação e o bem-estar próprios, ou seja, mais simplesmente, amar os meios para viabilizar a felicidade (Holbach 10, p. 60).

A virtude seria a utilidade dos Homens que vivem em sociedade. Seria equivalente dizer ser virtuoso e ser sociável: isso significaria ser aquele que contribui para a felicidade daqueles vinculados pelo destino, para que estes possam ser 
estimulados a contribuir também para a felicidade dos demais. A virtude é exatamente o que garante a utilidade, a felicidade e a segurança da sociedade (Holbach 9, p. 10 e 45) e a disposição que todo Homem deve deter para viver em sociedade (Holbach 11, p. 19).

Mais a Sociedade lhe assegura tais bens, mais ela será perfeita, mais ela lhe será estimada, mais ela se lhe tornará necessária. Ao amar seus associados, ele não amará senão a si mesmo; ao assegurá-los, ele não assegurará senão a si próprio; ao se sacrificar para ela, não é senão à própria felicidade que ele se sacrifica. (Holbach 9, p. 10, tradução nossa).

A Natureza não constituiria os Homens como bons ou maus, porque essa espécie de juízo não estaria no registro daquilo que é natural (Holbach 10, p. 10). A perversidade apenas adviria dos vícios da sociedade, a qual se mostra incapaz de assegurar a satisfação da felicidade e da conservação de cada um de seus membros de maneira útil aos demais. O parâmetro para estabelecer o que é virtuoso deveria considerar (i) o amor-próprio natural de cada indivíduo - busca do maior número de vantagens pela doação útil dos outros a si, e (ii) a doação útil de cada indivíduo aos demais (Holbach 9, p. 10).

Por isso mesmo, lembre-se de que as paixões são condições intrínsecas ao Homem, próprias dele e inevitáveis. Um Homem é qualificado como virtuoso, não porque não detém afecção por qualquer paixão, mas porque cada uma delas é dirigida utilmente para ele mesmo e para os outros com os quais se associou. A virtude é virtude social porque mantém e reforça os laços naturais da sociedade, enquanto que o vício tem por objetivo um fim diverso (Holbach 10, p. 10-1 e 119).

A virtude social proviria da utilidade social, ao passo que o vício seria engendrado pelos danos aos homens, ou seja, por uma ação prejudicial a si próprio e aos demais. Nesta situação, os laços sociais são distendidos e relaxados e o Homem se distancia da sociedade: ao agir deste modo, ele se torna inimigo, pois procura a satisfação de seus desejos fora do social e de maneira até mesmo contrária a ele (Holbach 9, p. 10-1; 10, p. 116-7).

Esta condição explicaria o surgimento de criminosos e de viciados, aqueles que buscam apenas a realização de um interesse pessoal e cego, inclusive por meio da violação deliberada das Leis - situação em que cada Homem se torna inimigo de outro Homem, e na qual o Estado Natural social se revela similar ao estado selvagem. Nestes casos, o cidadão virtuoso abandona a sociedade ingrata que não o serve e que apenas o 
oprime, diferentemente do cidadão viciado, pois este age como se estivesse isolado, como se estivesse só, apesar de estar no interior de uma sociedade (Holbach 9, p. 13-4).

Mais do que isso, em momentos de calamidade pública, a sociedade se manifesta como composta por membros em completa discórdia, razão pela qual o estado selvagem se mostra mais vantajoso do que o social - afinal, se mostra mais vantajoso viver sozinho do que rodeado por seres injustos perpetuamente preocupados em se manter em conflito (Holbach 9, p. 47). Virtuosas são as disposições úteis à sociedade; vícios são aqueles que mediata ou imediatamente recusam o bem-estar da espécie humana (Holbach 10, p. 118).

A Moral constitui deveres mútuos e recíprocos entre os membros da sociedade para a felicidade e o bem-estar individuais. Esses deveres oriundos das relações derivadas da necessidade de convivência são estabelecidos por um pacto social fundado na Natureza, nem escrito, nem claramente enunciado, mas que, de tão real (Holbach 11, p. 4 e 11), é renovado a cada nova criança que nasce na sociedade, sempre com o objetivo de garantir ao Homem bens maiores do que se ele estivesse isolado.

Os termos desse pacto permanecem os mesmos, estejam eles expressos, estejam eles sem vestígio material: o Homem deve buscar a felicidade de todos, e isso apenas é possível se viver em sociedade (Holbach 11, p. 11). A situação mais vantajosa da sociedade existe para que o Homem racional sempre a prefira à solidão eventual, pois por natureza o Homem moralmente deve seguir e amar os meios que ela lhe fornece para alcançar seu objetivo (Holbach 9, p. 12-3). O mal moral adviria daquele que busca a felicidade por meio da infelicidade dos demais (Holbach 9, p. 24; 10, p. 70).

"Ajudem-me, diz-lhe, e eu os ajudarei com minhas forças; emprestemme seus recursos, e vocês poderão contar com os meus: trabalhem para minha felicidade, se desejam que eu me ocupe da de vocês: partilhem de meus infortúnios, e eu partilharei dos seus. Deem-me vantagens suficientemente grandes, para eu me engajar a sacrificar por vocês um parte daquelas que possuo." A Sociedade lhe responde, "ponha em comum tuas faculdades, assim forneceremos nosso socorro; multiplicaremos tuas forças; trabalharemos de forma concertada para tua felicidade; aliviaremos tuas penas, asseguraremos teu repouso e nossos esforços reunidos afastarão de ti os males que temes com muito mais energia do que faria sem nós. As forças de todos te protegerão, a prudência de todos te esclarecerá, as vontades de todos te guiarão." (Holbach 9, p. 12-3, tradução nossa). 
É importante frisar que HOLBACH atribui à Natureza o fundamento das Leis físicas e morais, tendo em vista que as regras seriam resultado das relações necessárias que derivam da natureza das coisas (Holbach 9, p. 26). Por isso, a origem e o fundamento natural das Leis na sociedade natural de HOLBACH correspondem à natureza humana ela mesma. Se a necessidade forçaria a reunião de Homens, da mesma maneira ela lhes forneceria meios e condições - os deveres legais - para a manutenção dessa associação útil e mais vantajosa (Holbach 9, p. 14-5 e 26).

Estes deveres racionalmente estabelecidos são conteúdo das leis naturais; as leis devem ser concebidas como meros instrumentos da Moral porque objetivam estimular a prática virtuosa e tornar a Moral efetiva e eficaz (Holbach 10, p. 61-2). As leis derivam, deste modo, da natureza e da essência humanas que objetivam assegurar ao Homem a possibilidade de o manter atado a sua existência e de conservá-la, em razão do amor que tem por ela. $\mathrm{O}$ caráter natural dessas mesmas leis também decorreria da atração que todo Homem experimenta pelo útil e pelo agradável, bem como da aversão por tudo o que se revela prejudicial e infeliz (Holbach 9, p. 14).

\begin{abstract}
A partir destas condições, cada cidadão adquire direitos sobre a Sociedade que, para sua própria conservação, está obrigada a ser fiel a seus compromissos. Diante dessas vantagens, o cidadão, de seu lado, se compromete a ser justo, a subordinar seus interesses pessoais aos da Sociedade, a submeter suas vontades à dela, a defendê-la com todas suas forças, a sacrificar a porção de seus próprios bens para a conservação e a prosperidade de todos, a servi-la com seus talentos, com suas luzes, com suas faculdades, a não perturbar seus associados em suas profissões, a mantê-la com todo seu poder, a cooperar segundo suas forças à prosperidade geral, da qual depende a própria. A partir do momento em que ele cumpre fielmente esses compromissos, a Sociedade não pode sem injustiça privar o cidadão da felicidade que ela mesma se comprometeu a the fornecer. (Holbach 11, p. 4-5, tradução nossa).
\end{abstract}

A Natureza é o fundamento das Leis. Pela necessidade de aproximar o Homem do bem e de afastá-lo do mal, a natureza do Homem adquire autoridade suficiente para lhe impor obrigações destinadas a lhes servir dos instrumentos convenientes para a obtenção do prazer e para evitar a dor no interior da própria sociedade. Todas as leis detêm a mesma fonte, isto é, derivam da natureza humana, na medida em que sempre visam ao bem-estar dos Homens, ou seja, à obtenção de todas as felicidades e as utilidades oriundas do estar em sociedade (Holbach 9, p. 16 e 26). 
De fato, as recompensas pela observância das leis são a felicidade, a abundância e a tranquilidade da sociedade e de cada um de seus membros - pois a estima, o reconhecimento e a glória costumam os acompanhar. Por outro lado, as punições aplicadas aos infratores que se recusam a elas se submeter consistem no infortúnio, na discórdia, no vício, no crime e na destruição, haja vista que o ódio, o desprezo e a infâmia se instalam sobre estes. Tratam-se de consequências que consistem em estados diversos da consciência do cumpridor e do infrator (Holbach 9, p. 14-6).

Há que se notar, inclusive, que tais leis naturais seriam simples, claras e inteligíveis por cada habitante da Terra, razão pela qual ela careceriam da necessidade de serem promulgadas para estabelecer as regras de conduta típicas de um ser naturalmente social. Afinal, as leis estão em conformidade imediata com a Natureza, de modo que aquilo que se deve aos outros é exatamente o que se quer. Elas são facilmente descobertas por todos aqueles que se voltam sobre si mesmos com o objetivo de encontrar um guia para sua ação em relação aos seus semelhantes. Todos os seres humanos receberam da Natureza os mesmos direitos, sobre os quais todos detêm conhecimento, pois têm as mesmas aversões e as mesmas necessidades (Holbach 9, p. 15 e 27).

As constantes violações das leis naturais necessárias para a manutenção da sociedade são explicadas pela ignorância e pela falsidade que assolam as sociedades naturais humanas. $\mathrm{O}$ descumprimento das leis apenas exsurge de sua ignorância acerca de seus verdadeiros interesses, acerca dos verdadeiros fins da associação e acerca das desvantagens reais que derivam de seu isolamento (Holbach 9, p. 16-7), um desconhecimento da virtude social, de seu conteúdo e de seus fins.

Deste modo, não seria a Natureza a fonte da corrupção dos Homens, ela não os tornaria maus; antes, a origem residiria na carência de uma meditação mais acertada sobre a natureza da necessidade de um ser sensível viver em sociedade conforme os termos do pacto social celebrado (Holbach 9, p. 16-8; 11, p. 1-2).

Tudo se torna impulsão cega; por essa desordem a Sociedade é perturbada em sua tendência; sua conservação é ameaçada. Para repelir os males do quais ela sofre, ela se reúne contra aqueles de seus membros cujas paixões lhe são prejudiciais, ela lhe opõe uma força capaz de os conter. Essa força é a Lei, ou a expressão das vontades e dos interesses de todos, oposta às vontades ou aos interesses dos particulares. A Lei é a razão da Sociedade que se eleva contra a 
desrazão de alguns de seus membros, a fim de os trazer de volta ao fim da associação. (Holbach 9, p. 25, grifos do autor, tradução nossa).

Com efeito, haveria uma ausência de reflexão esclarecida sobre a natureza, sobre os fins e sobre os efeitos da sociedade, bem como sobre os deveres e sobre os direitos derivados dessa vida. Essa pensar não esclarecido derivaria de uma distração em razão das ocupações e dos entretenimentos que obstam o acesso às causas das coisas e, portanto, de óbices à percepção da necessidade de um agir moral socialmente virtuoso. Também a Religião seria um impedimento a essa compreensão mais adequada da sociedade, na medida em que ela direcionaria os Homens a uma preocupação com questões não-materiais e não-terrenas do além-mundo - por supor o presente como mera passagem, o que tenderia a relaxar os laços sociais (Holbach 11, p. 2-3).

HOLBACH opõe ainda a vontade particular à vontade geral. Enquanto a primeira seria comumente violenta, precipitada e desarrazoada, pois norteada passionalmente pela inconstância, a última seria mais calma, tendo em vista que todos os indivíduos em conjunto não padeceriam das mesmas paixões, sendo facilmente julgáveis as paixões uns dos outros. O jogo entre as forças das imperfeições de uns Homens injustos contra outros permitiria chegar a um resultado legal possivelmente justo, porque um avaliaria e controlaria a injustiça do outro, e vice-versa (Holbach 9, p. 25-6; 11, p. 3).

As leis naturais sinalizariam aos Homens todas as vantagens de uma vida em sociedade, motivo pelo qual elas deveriam ser mantidas igualmente a todos os associados como fonte das mesmas utilidades. As leis naturais são aquelas que derivam imediatamente da natureza humana (Holbach 11, p. 7): o próprio desejo equivaleria ao desejo dos demais, pois "todos são os filhos da Natureza como nós, com os mesmos desejos, com as mesmas necessidades, com as mesmas aversões” (Holbach 9, p. 27, tradução nossa).

Também existiriam as leis civis, ou leis políticas, que se diferenciariam das leis naturais em razão de serem aplicadas às circunstâncias e às necessidades de uma sociedade em particular, estabelecendo os deveres e os direitos de seus membros (Holbach 9, p. 28; 11, p. 6). Todavia, as leis civis não poderiam deixar de ser consideradas como leis naturais, pois, para serem justas e racionais, deveriam estar fundadas na Natureza dos Homens (Holbach 9, p. 28). 
Deve-se salientar que, assim, as leis civis podem divergir das leis naturais, como comumente fazem (Holbach 10, p. 105), mas elas apenas poderão ser justas e razoáveis quando consistirem na aplicação das leis da natureza humana às circunstâncias momentâneas. A injustiça das leis civis deriva justamente da incompatibilidade destas com as leis naturais, tão essenciais e necessárias ao Homem que não devem ser enfraquecidas ou ab-rogadas pelo capricho dos interesses e da força daqueles que as impõem sobre a sociedade em detrimento desta (Holbach 9, p. 29-30).

Com efeito, as leis naturais são impassíveis de suspensão no estado social, porque isso significaria privar o Homem de seu bem-estar, na medida em que o estar em sociedade não altera a natureza humana (Holbach 11, p. 7) - por, afinal, a sociedade ser Natureza.

\begin{abstract}
As ações conforme a nossa natureza, ou seja, aquelas que as leis naturais ordenam ou permitem, são justas. As ações contrárias à nossa natureza - ou o que as Leis Naturais impedem - são injustas. Assim, tudo aquilo que as leis da natureza permitem é justo e legítimo ; tudo o que as leis da nossa natureza proíbem é injusto e ilegítimo. Para que uma lei seja justa, ela deve estar conforme à Natureza ; ela se torna injusta a partir do momento que ela a contradiz. A Sociedade somente tem a crença de aplicar as leis da Natureza a suas necessidades atuais, ou de aplicá-las às circunstâncias particulares nas quais ela se encontre. Ela não pode jamais as derogar ou as destruir, visto que, com isso, ela trabalharia para sua própria ruína. (Holbach 9, p. 36, tradução nossa).
\end{abstract}

A lei civil apenas será justa e razoável quando a sociedade - ou aquele a quem ela atribui a autoridade de regular a vontade de seus membros - traduzir, nos termos da lei civil, as leis que derivam imediatamente da natureza humana. A justiça da lei civil será constatada quando for vantajosa para todos os membros da sociedade, isto é, quando assegurar a manutenção dela e de seus laços sociais (Holbach 9, p. 28-9; 11, p. 7). Em suma, será justa somente se não privar o Homem da liberdade, da segurança, da propriedade ou da certeza de fruição das vantagens decorrentes da vida em sociedade (Holbach 11, p. 8).

Assim, apenas será um direito aquela faculdade de agir que for aprovada pela lei natural ou pela lei civil - sempre conforme a lei natural (Holbach 9, p. 35). Afinal, apenas deste modo seria uma ação conforme a justiça ou conforme a utilidade da 
sociedade (Holbach 10, p. 106). Deste modo, uma lei injusta não poderia jamais conferir qualquer direito aos Homens (Holbach 11, p. 8).

As leis naturais e seus respectivos direitos são eternos e invariáveis, tendo em vista que duram conforme a duração da humanidade. No entanto, a aplicação deles é variável, dependendo de circunstâncias, de condições e de necessidades de cada sociedade. Essa matização é realizada pela lei civil e por seus respectivos direitos, pois cada sociedade está sujeita a vicissitudes e a mudanças típicas, como todo e qualquer ser (Holbach 9, p. 28-9 e 35; 11, p. 7-8).

As mesmas leis civis podem não se mostrar convenientes, úteis e benéficas com a variação temporal; todavia, não devem descuidar nunca do bem e da utilidade geral da sociedade, pois são orientadas a produzir a felicidade para o maior número possível de indivíduos. Em todos os países, o Homem é sempre o mesmo, com os mesmos desejos, apesar de os meios de satisfazê-los variarem (Holbach 9, p. 28-9 e 35; 11, p. 7-8).

Todas as Leis que não tenham essas características são repudiadas pela razão, elas não são feitas para obrigar seres racionais; elas não podem conferir direitos, elas são os efeitos da tirania e de uma violência à qual a Sociedade pode sempre se opor.

Uma Lei é injusta quando tem por objeto a utilidade de um só ou de um pequeno número e quando ela é prejudicial ao resto da Sociedade. Uma Lei é injusta quando tende a relaxar ou a destruir os laços de uma sociedade que ela deve manter. (Holbach 9, p. 29, tradução nossa).

Mesmo o direito das gentes seria fundado na Natureza. Cada uma das nações manteria uma relação de deveres com as outras de maneira igual à que um indivíduo mantém com os demais de sua mesma sociedade, tendo em vista que a grande sociedade do mundo se regeria pelas mesmas leis naturais (Holbach 11, p. 20). Assim, uma nação não poderia prejudicar, destruir ou privar outra; pelo contrário, uma nação deveria permanentemente visar à vantagem geral e estar imbuída de justiça, de boa-fé e de humanidade, isto é, deveria ceder parcela de seus direitos aos direitos das outras nações (Holbach 9, p. 30-2); afinal

se não podemos exigir o amor e os benefícios daqueles que nos são estrangeiros, temos ao menos o direito de exigir que eles sejam justos conosco, pois cada indivíduo de nossa espécie tem o direito de o exigir de nós. (Holbach 10, p. 108, tradução nossa). 
As nações seriam como indivíduos da sociedade universal ou da espécie humana: um povo deve a outro tudo aquilo que um Homem deve a outro Homem, exatamente por não haver duas morais diversas para a espécie humana. Os mesmos laços de união entre amigos unem as nações aliadas, e os mesmos laços de humanidade e de equidade unem entre si os povos - mesmo os mais estrangeiros, os mais distantes e os mais divididos em função de interesses (Holbach 11, p. 109).

\subsection{Fundamento e Limites Naturais do Governo}

Como afirmado acima, a expansão das famílias teria gerado as sociedades e os Governos, na medida em que o primeiro Rei teria sido um pai de família (Holbach 9, p. $56)^{4}$. Enquanto organização social natural, todo Governo apenas teria por objetivo assegurar a observância do justo na sociedade, a fim de que esta subsistisse - por a felicidade social ser o fim de qualquer Governo (Holbach 9, p. 47-8).

Os critérios naturais para a escolha de um Governo são a bondade e a utilidade. Os Homens elegeriam seus governantes pelo mero "voltar os olhos naturalmente em direção àqueles dos quais receberam o maior número de benfeitorias, e sobre os quais se acredita haver possibilidade de receber ainda mais" (Holbach 9, p. 56, tradução nossa). O governante escolhido é o mais útil a seus semelhantes, em nome e em benefício destes (Holbach 11, p. 11), sendo este o fundamento natural da hierarquia política (Holbach 10, p. 140).

O Governo seria o instrumento da Moral destinado a estimular a prática virtuosa e a tornar a Moral efetiva e eficaz ${ }^{5}$ (Holbach 10, p. 61-2): os Homens somente obedecem a um deles se sem este não puderem ser felizes (Holbach 11, p. 11). O Governo estaria essencialmente vinculado ao fundamento natural da sociedade, pois ela se organizaria politicamente em torno de uma autoridade poderosa representante da vontade de todos no atendimento útil dos fins naturais (Holbach 10, p. 140; 11, p. 18).

Finalisticamente, portanto: o Governo é constituído para os Homens serem mais felizes e mais tranquilos por meio da proteção - com relação aos vícios dos de dentro ou aos empreendimentos dos de fora - e por meio da percepção de maior número de recursos (Holbach 9, p. 48 e 56-7). Este chefe não adquirirá nunca o direito de lhes negligenciar a felicidade, detendo apenas naturalmente aqueles direitos que a nação lhe atribuir, os quais consistem precisamente em mecanismos voltados a assegurar a 
realização do invariável fim da sociedade: tornar seus membros felizes e conservá-los nessa situação por meio de leis equânimes e justas (Holbach 11, p. 12 e 18).

O Governo é a soma das forças da Sociedade depositadas nas mãos daqueles que ela julgou os mais próprios para a conduzir à felicidade. De onde segue evidentemente que um Soberano não é o Mestre da Sociedade, mas seu Ministro, encarregado de cumprir os compromissos em relação aos cidadãos e munido do poder necessário para obrigá-los a cumprir os seus. (Holbach 11, p. 6, tradução nossa).

Nestes termos, o fundamento do Poder político do Governo - a autoridade a quem se submetem os membros da sociedade para que alcancem os objetivos naturais almejados pela associação - é a própria Natureza, pois o Governo não poderá ser injusto, nem poderá tornar a sociedade miserável, tendo em vista que a própria sociedade não busca enfraquecer sua sorte (Holbach 9, p. 48). Sua legitimidade deriva de sua disposição em proporcionar vantagens à sociedade para a tornar feliz (Holbach 11, p. 18-9).

Mais sinteticamente, para HOLBACH, o fundamento do Poder político é pura e simplesmente a Natureza (Holbach 9, p. 54 e 81-2), e não qualquer estado anterior de guerras e de conquista, nem mesmo uma superstição religiosa legitimadora do despotismo que evita reconhecer o fundamento do Poder político diretamente na natureza dos Homens (Holbach 11, p. 15 e 17; 12, p. v-vi).

Por esse motivo, os Homens se submetem a uma autoridade portadora de vontade e de força próprias, as quais são orientadas à movimentação de toda a sociedade em direção ao bem geral: "a segurança, a felicidade, a conservação do todo e de suas partes" (Holbach 9, p. 53). Cada uma das partes da sociedade é conduzida pelo impulso iniciado no interior do Governo e tem suas vontades, suas faculdades e suas ações submetidas a esta força central - cujo fundamento é, em uma palavra, a Natureza, ou ainda, o se direcionar ao fim natural de toda e qualquer associação humana.

A necessidade de compatibilidade do Governo com os preceitos da natureza humana - ser sociável em razão de se visar a uma utilidade comum que torna a associação mais vantajosa do que o viver isolado - é a chave fundamental para compreender o pensamento do Barão de HOLBACH. Uma sociedade natural apenas se submeteria a uma força se esta não pretendesse a privar das vantagens necessárias a sua existência conforme as necessidades naturais de maiores felicidade e acesso a recursos 
(Holbach 9, p. 48). O Governo se reduz a um dirigir os Homens para que se mantenham em uma associação mútua e reciprocamente útil, que lhes assegure mais bem-estar, mais felicidade, mais satisfação de necessidades naturais. A igualdade entre os Homens consiste precisamente no dever de serem igualmente úteis ao fim natural do Estado, qual seja, o de assegurar a vantagem da associação (Holbach 10, p. 140).

\begin{abstract}
Nenhum homem renuncia gratuitamente a sua independência natural; apenas nos contentamos em nos submeter às vontades dos outros quando temos a esperança de um bem maior que daí resultasse para nós do que se seguíssemos nossas próprias vontades. O cidadão somente obecede à lei, à vontade pública e à autoridade soberana porque ele espera que elas o guiarão mais seguramente em direção à felicidade durável do que suas vontades particulares e suas fantasias [...]. (Holbach 9, p. 49).
\end{abstract}

Governar os membros de uma sociedade consistiria em os obrigar ao fiel cumprimento das condições do pacto social celebrado, ou ainda, seria convidá-los ou forçá-los a concorrerem ao bem público e a desempenharem suas virtudes sociais. Isto significa que governar seria um mecanismo de orientação dos membros da sociedade para a conservar por meio do reforço de seus laços, ou seja, por meio da manutenção da condição social geral mais vantajosa do que a condição isolada (Holbach 9, p. 51; 11, p. 20).

Assim, apenas se obedece em nome da felicidade e da realização do bem-estar, não havendo qualquer consentimento posterior por parte dos Homens escravos que legitime o usurpador (Holbach 11, p. 15-6). Por nem sempre os Homens agirem racionalmente, por nascerem com paixões que os cegam com relação aos fins da sociedade e com referência aos deveres e aos direitos mútuos, eles têm necessidade de se submeter a uma autoridade que os direcione para o resultado da máxima vantagem derivada da associação. Deste modo, o Governo e as Leis surgem apenas para dever orientar os Homens ao atendimento de sua Natureza (Holbach 9, p. 51-2 e 54; 10, p. $141 ; 11$, p. 6-7).

A instituição do Governo se articula como força que substitui as paixões racionalizadas individuais e que impõe a observância das leis e das regras da sociedade para sobrepor o bem geral aos interesses particulares. O Governo força os homens a praticarem a virtude social, a fim de evitar o esgarçamento do tecido social mediante a 
garantia da impossibilidade de ascensão da rivalidade entre seus membros (Holbach 9, p. $52-3 ; 11$, p. 20$)$.

Haveria um limite ao Poder político definido por seu próprio fundamento - a Natureza. A demarcação precisa da fronteira entre a capacidade de mando-obediência estaria alicerçada na Natureza, pois o Governo não poderia se esquivar da busca pela justiça e do interesse geral. $\mathrm{O}$ divisor de águas que justificaria a relação mandoobediência (a autoridade e a dependência) consistiria exatamente em um Governo afeito ao bem-estar e à felicidade dos membros da sociedade, não se admitindo um Governo que utilizasse a força de acordo com seus caprichos não-naturais (Holbach 9, p. 54; 10, p. 141-2).

Inclusive, não seria possível crer que em razão de delírio, de ignorância, de entusiasmo, ou mesmo em virtude de sujeição por uma força violenta, uma sociedade perderia o direito de reclamar, de protestar e de se defender contra uma usurpação praticada por um que deveria a proteger. Mesmo se renunciar a seus direitos, "[o]s direitos da sociedade são por natureza eternos e inalienáveis, [e] aqueles da violência não podem jamais se tornar direitos sagrados.” (Holbach 9, p. 48, tradução nossa).

No entanto, para HOLBACH, não se mostraria admissível a prática revolucionária, geralmente originada da paixão, do furor e da necessidade - e não da Natureza. Sua tendência é substituir um Governo mau por um Governo mais perigoso e mais contrário à Natureza. Um movimento revolucionário engendrado sob a alcunha de liberdade pode significar na verdade uma licença que prejudicaria a sociedade e aquele que a exerce impacientemente em nome de uma independência ilimitada ou de um interesse pessoal (Holbach 10, p. 145).

Segundo o autor, apesar de trazerem às vezes bens momentâneos, as revoluções no mais das vezes introduzem calamidades duráveis. Deve-se deixar a Natureza agir por si só, devendo os Homens racionais submetidos a um Governo ruim aguardar com paciência a ação lenta, porém eficaz, da Natureza. Apenas desta maneira a vontade tranquila da sociedade se manifesta para apontar a anti-natureza do Governo, sem agitações intestinas que redobrassem a destruição originada pela autoridade que se orienta em direção oposta ao bem-estar e à utilidade sociais (Holbach 9, p. 79-85).

Após o breve delineamento do fundamento natural da sociedade, de suas Leis, bem como de seu Poder político no interior do pensamento político do materialismo ateu do Barão de HOLBACH, deve-se indagar acerca da possibilidade de esse 
fundamento atribuído à Natureza consistir, ou não, em um mecanismo perpetuador do teológico-político, questão a ser examinada no item a seguir.

\section{A Permanência do Teológico-Político no Materialismo Ateu}

Perceba-se que é possível constatar haver a persistência do teológico-político também na concepção materialista do século XVIII acerca do fundamento da lei e do Poder político, ainda que sob outro nome (Natureza), tal qual ocorre nas explicações religiosas do Poder político que são criticadas pelo próprio materialismo ateu.

Apesar de não consistir em uma explicação religiosa de matriz cristã do fundamento do Poder político, pode-se perceber que se trata de uma compreensão bastante similar e análoga, ainda que laica. Note-se que se continua a atribuir a esfera externa ao Homem - para sobre ele retornar e se impor - o fundamento da lei e do Poder. Não se trata mais da razão natural revelada de origem divina, ou nem ainda da razão natural humana, mas da Natureza em si como fundamento laico do social, da moral e da Política. E, como todas

ideias de razão, de justiça e de direto, que comandam um retorno aos princípios do pensamento clássico e um movimento em direção de uma ética laica, também est[á] ligada a uma elaboração teológico-política. (Lefort 14, p. 291).

Parece ser possível diagnosticar a reafirmação da crença de que a lei deteria um fundamento não no Homem, mas em entidade externa a ele, em uma entidade que lhe transcende. Não a Justiça (por não haver essa categoria no natural), um Deus ou uma Religião, mas a Natureza - algo também externo à medida humana - preencheria completamente o lugar do Poder - que nunca está vazio. Mais uma vez, haveria a compreensão de o Homem ser por ele mesmo incapaz de fundar uma lei para si mesmo o que denotaria a persistência de uma concepção teológico-política de organização da sociedade.

A crença do materialismo ateu em atribuir a uma entidade externa ao Homem - a Natureza - o fundamento da Lei e do Político certamente não se trata de uma explicação de ordem religiosa em termos clássicos tal qual combatida por eles no século XVIII exatamente por não se referenciar a Deus. No entanto, é possível apontar em caráter analógico essa qualificação precisamente porque, ao atribuir a entidade transcendente ao 
Homem tal posição de fundamento da Lei e do Político, retira dele a capacidade de determinar sua Lei e sua Política, substituindo-o pela Natureza como a ocupante intemporal do lugar do Poder político.

No sentido de sinalizar a permanência do teológico-político na reflexão política do materialismo ateu, é sintomático lembrar que tais autores afirmavam se fundar na crítica de Espinosa aos regimes teológico-políticos:

Conhecemos a resposta de Espinosa: os regimes políticos violentos são conservados por meio da superstição, do medo de castigos, da esperança de benefícios, da censura do pensamento e da palavra, da submissão aos poderes religiosos e teológicos. Eis por que a filosofia espinosana ergue-se contra essas formas de dominação, pois aprisionam os espíritos, submetem as consciências, alimentam a tristeza, o ódio e o medo, enfraquecendo o conatus de cada um e o do sujeito político coletivo. (Chauí 5, p. 71, grifos do autor).

No entanto, também é sintomática, apesar de descontextualizada, a conhecida equalização apontada por Espinosa entre Deus e Natureza em sua alternativa Deus sive natura (Chauí 5, p. 44). Esta aproximação entre Deus e Natureza na metafísica espinosana pode ser sutil e ironicamente ressignificada para uma melhor compreensão do pensamento político do materialismo ateu; nele, ter-se-ia operado, a final, a substituição de Deus pela Natureza no exercício da função simbólica de preencher intemporalmente o lugar do Poder político.

Nesse sentido, o Homem enquanto fundamento direto da Lei e do Poder político estaria ainda assim sendo apresentado a partir de determinado perfil, ou ainda, mediatamente, por meio da Natureza. Esta seria caracterizada como o critério por excelência para a explicação de fenômenos e para a justificação de normas sociais, morais, éticas, políticas e jurídicas: se, por um lado, o fundamento não é a religião, também não é o Homem.

O materialismo ateu é caracterizado pela utilização da Natureza como critério explicativo da realidade. Ao retirar Deus (ou outra religião) do centro das explicações para colocar a Natureza em seu lugar, ele opera uma simples substituição de entidade diversa do próprio Homem para ocupar o lugar do Poder de maneira intemporal e absoluta. Não seria ainda diretamente o Homem o fundamento do Poder político e das Leis, mas apenas ele e seu mundo enquanto mediatizados pela Natureza e pela concepção que tivessem dela. 
Há, nesse sentido, uma dupla recusa no pensamento político do materialismo ateu sobre o fundamento do Poder político, a saber, a rejeição de explicações religiosas e, concomitantemente, de explicações humanas. Se afasta o teológico-político por meio da repulsa a uma referência religiosa de matriz cristã, o materialismo ateu reintroduz a variável de organização social teológico-política por outro foco, qual seja, pela negativa ao Homem de ser tal fundamento, ou seja, por meio da admissão de ser Outro diverso do Homem para constituir o princípio instituidor do Poder político - a Natureza.

Deste modo, parece que o materialismo ateu, a despeito de criticar o fundamento religioso-cristão do Poder político, permanece teológico-político com sua concepção do princípio do Político que instaura a sociedade e que a organiza. De fato, atribui à Natureza, e não ao Homem, exatamente as mesmas prerrogativas e expectativas que se pretendia extrair de Deus ou de qualquer outra religião: o fundamento do social, do Político, da Lei e da Moral. A Natureza seria o ocupante "natural" do lugar do Poder, preenchendo-o plena e intemporalmente e excluindo qualquer outro critério.

O natural consistiria, assim, em uma entidade que incorporaria o Poder e que se identificaria com ele, sendo o Poder. Este seria encarnado por essa entidade transcendente ao Homem que, mantida nessa condição, é reconhecida como tendo recebido a exclusividade de ocupação intemporal do lugar do Poder pelos próprios Homens, e no lugar deles, em substituição à Religião. Em outras palavras, esta entidade Outra ao Homem, conforme sua medida de entidade Outra, seria o padrão que orientaria jurídica, política, moral e socialmente o Homem.

Com efeito, a partir do item precedente, percebe-se que o materialismo ateu valorizava a Natureza e a entendia como apta a explicar o mundo e as relações humanas a partir de uma unidade e de leis que seriam próprias do natural, alheias a qualquer interferência de origem humana. O Homem ou o sujeito não deteriam a aptidão para explicar o mundo a partir de si mesmos, pois essa qualidade apenas seria detida pela Natureza.

Pois bem. A Natureza - conforme construída pela tradição do pensamento do materialismo ateu - não deve ser considerada como o fundamento da Lei, pois se trata de categoria que persiste em apresentar apenas parcialmente a condição humana. Revela-se, assim, como mais um possível artifício não-observável produzido pelas crenças do caldo cultural humano para o qual se pode atribuir o fundamento da Lei.

Por isso mesmo, entender ser a Natureza o fundamento da Lei é persistir igualmente em uma crença costumeiramente construída em um elemento que apenas 
mediatiza a plural condição antropológica humana como o centro da gênese da Lei. Trata-se de permanecer na condição teológico-política porque se continua a atribuir a uma entidade diversa do próprio Homem o caráter de fundamento da Lei - ainda que o argumento da Natureza emule de maneira eficaz o fundamento humano do Direito e do Poder político.

Reproduz-se, assim, a lógica de atribuir a outrem o fundamento do Poder e do Direito, preservando a percepção, o discurso e a perspectiva de ser o fundamento algo semelhante à fé religiosa - da mesma maneira que ocorre com o recurso a expressões unificadoras tão vagas como identidade, nação, razão de Estado, humanidade, proletariado, raça, povo e espírito (Lefort 14, p. 268-9, 271 e 286). Ou seja, trata-se de uma situação que, em suma, assegura a persistência do fundamento teológico-político do Poder e de sua Lei, porque estes são dados por um Outro, inumano, que tenta salvar do exterior a humanidade, por meio da unidade da fé.

[C]om relação à questão que colocávamos, a similitude dos projetos é impressionante. Trata-se, de uma maneira ou de outra, de dar ao poder uma realidade substancial, trazer para sua órbita o princípio da Lei e do Saber; denegar a divisão social sob todas as suas formas; refazer a sociedade de um corpo. [... A] vinculação com o religioso, que assinalávamos, os confina na ilusão de uma restauração da unidade e da identidade enquanto tal, que eles vêem se anunciar na união do corpo social. [... C]edem à atração por uma certeza restituída [...]. (Lefort 14, p. 271, grifos do autor).

Há que se reconhecer, no entanto, as inconveniências de se persistir em um discurso que escolha um fundamento das Leis transcendente ao Homem, isto é, um fundamento que recuse a imediatez da imanente condição antropológica humana.

Atribuir o fundamento da Lei a uma entidade externa ao Homem significa retirar dele a condição de viver ativamente a Lei para a experienciar diuturnamente, seja para reafirmá-la ao modo como seus antepassados, seja para alterá-la imperceptivelmente. Entender ser a Natureza o fundamento da Lei e do Poder político significa o exprimir, e não o manter impresso dentro da interioridade viva humana. É uma maneira de fazer incidir sobre o Homem soberanamente o poder de sujeição de uma criatura sua que é essencialmente datada, falha, potencial e rigorosamente específica e opressora: tudo o que não for natural deve ser sumariamente abolido e substituído. 
Nesse sentido, é interessante mencionar o desenvolvimento prático do Projeto de Descristianização do Estado e da sociedade civil francesa operado durante a Revolução Francesa. Neste momento, é possível identificar esse duplo movimento de afastamento com relação ao teológico-político do Antigo Regime e de aproximação do teológicopolítico, por vias transversas, no princípio de instauração do Político da nova ordem social (Souza 20).

Há que se lembrar, por exemplo, que, com a Constituição Civil do Clero, houve o estímulo ao casamento de padres com suas amantes, de padres entre si, a organização de festivais civis e revolucionários anticlericais, compreendendo fogueiras de batinas e incendeio de diplomas de atribuição de autoridade religiosa (Souza 20).

Mais sintomáticos do movimento de abolição do não-natural com o objetivo de afastar uma compreensão teológico-política de fundo religioso-cristão, podem ser mencionados os empreendimentos populares tomados pelo excesso revolucionário, como a fundição de sinos, a destruição de símbolos, o escárnio de padres e a prática de diversas libertinagens em festas realizadas em antigos templos religiosos. Os próprios carnets de doléances sinalizavam o desejo popular no sentido de eliminar frades, padres e freiras, cidadãos ociosos dos mosteiros e dos conventos (Souza, 20).

A adoção do Calendário Republicano também é símbolo do processo de laicização natural do Estado e da sociedade civil franceses. Com efeito, pretendeu-se substituir os nomes de meses e de dias do ano, tradicionalmente atribuídos a santos, por nomes da Natureza (camomila, faia, tulipa, brumário, ...) de acordo com cálculos que combinavam com a Astronomia - inclusive, com um relógio republicano (Souza 20).

Nesse sentido, percebe-se que este Projeto Revolucionário de instauração de nova ordem sócio-política tinha por objetivo a retirada da referência simbólico-religiosa de diferentes credos (cristão, judaico, adventista do sétimo dia, entre outros). No entanto, apesar de buscar afastar o teológico-político do Antigo Regime, é interessante notar que o medo de difusão do ateísmo, ou seja, da descrença absoluta em qualquer entidade, foi a característica do Terror, bastando mencionar a instauração, sob o mando de Robespierre, do culto do Ser Supremo - uma substituição do cristianismo por algo bastante semelhante a ele mesmo (Souza 20).

Nesse sentido, a crença de que o povo precisava de uma religião em que acreditasse se mostrou fundamental - ainda que não devesse significar o retrocesso à crença na religião cristã. Percebe-se, a final, o retorno do teológico-político enquanto princípio de instauração do Político - apesar de inicialmente afastado com as práticas 
revolucionárias, e ainda que por via diversa, laicizada, racionalizada e naturalizada. A nova ordem sócio-política seria erigida em torno de princípio tão teológico-político quanto a anterior - mas, agora, de fundamento naturalista (Souza 20).

Especial atenção deve ser dada ao objetivo de associar o culto ao Ser Supremo pelo movimento revolucionário francês com a ideia de que a República estaria nos planos do Ser Supremo, tal qual a Liberdade e a Justiça, por residir na Natureza. Essa justificativa foi o início do terror revolucionário: a partir da consagração republicana do Ser Supremo, houve a instauração de execuções públicas por meio de guilhotinas - de modo similar à fogueira dos hereges, organizadas como festas cívicas de afirmação do Ser Supremo - o que legitimou no período a República e a guilhotina (Souza 20).

\section{Conclusão}

O objetivo do presente trabalho consistiu em examinar se a proposta de fundamento do Poder político na Natureza do Projeto materialista ateu do Barão de HOLBACH poderia fornecer um fundamento político ou teológico-político da organização social. A escolha por este movimento intelectual específico se justifica porque ele visava à eliminação de um resquício religioso-cristão na orientação do Poder político do período por meio da laicização das compreensões sociais, políticas e morais vigentes.

Nesse sentido, em primeiro lugar, apresentou-se sucintamente a diferença entre uma organização social política e outra teológico-política. Em seguida, desenvolveramse considerações pontuais acerca da Política Natural de HOLBACH, com o objetivo de precisar sua proposta de fundamento do Político. Em terceiro lugar, avaliou-se o Projeto de HOLBACH, sendo possível aferir o caráter teológico-político do mesmo.

Foi possível perceber que, enquanto representante do materialismo ateu, a proposta do Barão de HOLBACH está bastante próxima de uma concepção teológicopolítica de organização do social, na medida em que aponta ser princípio absoluto e intemporal de instituição do político e do social elemento externo ao Homem, que o mediatiza a si mesmo: a Natureza. Apesar do objetivo de afastar uma explicação nãolaica da origem e do fundamento do Poder político, a concepção de uma Política Natural também encontra - ainda que secularmente - este fundamento em entidade que transcende os Homens, não derivando as Leis e o Poder diretamente do imanente ao Homem. 
Nesse sentido, apesar dos esforços de afastamento das explicações religiosas de matriz cristã para compreender o fundamento do Poder político, é possível concluir que a substituição da figura de Deus pela figura da Natureza apenas se tratou de uma modificação de imagem que preencheria intemporalmente o lugar do Poder, sem possibilidade da necessária alternância típica de uma organização política.

Deste modo, dada a ausência do lugar vazio do Poder apto a ser periodicamente preenchido mediante conflitos - conforme se esperaria de uma organização política do social, pode-se entender que o Projeto político do materialismo ateu de Barão de HOLBACH persistia em uma matriz de explicação teológico-política.

Espera-se, assim, que se tenha contribuído minimamente para o aprimoramento da compreensão do pensamento político desenvolvido pelo movimento do materialismo ateu do século XVIII, a fim de permitir a ampliação do círculo de discussões sobre o tema do fundamento do Poder político e das Leis.

\section{REFERÊNCIAS BIBLIOGRÁFICAS}

1. AlbuQUERQUE, Ruy de. Direito de Juristas - Direito de Estado, Revista da Faculdade de Direito da Universidade de Lisboa, Lisboa, v. XLII, n. 2, p. 751-801, jan. 2001.

2. ALTHUSSER, Louis. Sobre o Contrato Social. Lisboa: Iniciativas Editoriais, 1976.

3. AQUINO, Tomás de. O Ente e a Essência. Lisboa: Instituto Piaget, 2000.

4. CARDOSO, Sérgio. Do Desejo à Vontade - A Constituição da Sociedade Política em Rousseau, Discurso, São Paulo, v. 6, p. 35-60, 1975.

5. CHAUÍ, Marilena. Espinosa - Uma Filosofia da Liberdade. 2 ed. São Paulo: Moderna, 2005.

6. FAUCHET, Claude. Quatorzième Discours a l'Assemblée des Amis de la Verité, La Bouche de Fer, Paris, a. 3, n. 7, p. 97-107, jan. 1791.

7. FORTES, Luiz Roberto Salinas. Rousseau: Entre o Bem Dizer e o Bem Fazer, Discurso, São Paulo, v. 5, p. 5-27, 1974.

8. Rousseau: Da Teoria à Prática. São Paulo: Ática, 1976. 
9. HOLBACH, Paul Henri Dietrich (Baron de). La Politique Naturelle ou Discours sur les Vrais Principes du Gouvernement. t. I ${ }^{\mathrm{er}}$. Londres: s.e., 1773.

10. Systême Social ou Principes Naturels de la Morale et de la Politique Avec un Examen de l'Influence du Governement sur les Moeurs. t. I ${ }^{\mathrm{er}}$. Londres: s.e., 1773.

11. Systême Social ou Principes Naturels de la Morale et de la Politique Avec un Examen de l'Influence du Governement sur les Moeurs. t. II $^{\text {nd }}$. Londres: s.e., 1773.

12. Système de la Nature ou des Lois du Monde Physique et du Monde Moral. t. I ${ }^{\mathrm{er}}$. Paris: Étienne Ledoux, 1821.

13. LEBRUN, Gerard. Contrato Social ou Negócio de Otário?. In: LEBRUN, Gerard. A Filosofia e sua História. São Paulo: Cosac \& Naify, 2006.

14. LEFORT, Claude. Permanência do Teológico-Político? In: LEFORT, Claude. Pensando o Político - Ensaios sobre Democracia, Revolução e Liberdade. São Paulo/Rio de Janeiro: Paz e Terra, 1991.

15. NASCIMENTO, Milton Meira do. Rousseau, a Revolução e os Nossos Fantasmas, Discurso, São Paulo, v. 13, p. 169-85, 1983.

16. . O Contrato Social - Entre a Escala e o Programa, Discurso, São Paulo, v. 17, p. 119-29, 1988.

17. Opinião Pública e Revolução - Aspectos do Discurso Político na França Revolucionária. São Paulo: EDUSP/Nova Stella, 1989.

18. ROUSSEAU, Jean-Jacques. Discurso sobre a Seguinte Questão, Proposta pela Academia de Dijon: Qual é a Origem da Desigualdade entre os Homens, e é Ela Autorizada pela Lei Natural? In: ROUSSEAU, Jean-Jacques. Rousseau. 3 ed. São Paulo: Abril, 1983. p. 215-82. (Col. Os Pensadores).

19. O Contrato Social - Princípios do Direito Político. 4 ed. São Paulo: Martins Fontes, 2006.

20. SOUZA, Maria das Graças de. Materialismo das Luzes e Revolução Francesa. São Paulo: Faculdade de Filosofia, Letras e Ciências Humanas, Universidade de São Paulo, 2010. (Anotações da Décima Segunda Aula da Disciplina da Pós-Graduação). 


\section{PERMANENCE OF THE THEOLOGICAL-POLITICAL? AN ANALYSIS OF THE POLITICAL THOUGHT OF HOLBACH'S ATHEISTIC MATERIALISM FROM CLAUDE LEFORT}

Abstract: Departing from the analysis of the Political foundation which is proposed in some works from Baron of HOLBACH, this article aims to examine how eighteenth century's atheistic materialism comprehension on the foundations of Law and Politics is capable to signal to a political or to a theological-political organization principle of society, according to C. LEFORT's hermeneutical key. After a brief presentation of the difference between the Political and the Theological-Political and of Baron of HOLBACH's conception of Natural Politics (foundation of society, of Morality, of virtue and of the Laws and Government's political foundations and limits), it is possible to perceive the persistence of a theological-political principle within eighteenth century's materialism conceptions on Politics. This particular condition derives from the fact that God is replaced by Nature (transcendence) in the exercise of the symbolic role of fulfilling the place of Political Power.

Keywords: Political; Theological-Political; Foundation of Laws; Foundation of Power; atheistic materialism

\section{NOTAS}

${ }^{1}$ Parcela das pesquisas desenvolvidas para minha Tese de Doutorado A Integração como Fenômeno Jurídico-Político: Uma Leitura sobre a Construção Histórica da CECA - apresentada e defendida perante a FDUSP em setembro de 2013 - contribuiu para o desenvolvimento da chave hermenêutica lefortiana descrita no item 2. deste artigo (A Organização Política e a Organização Teológico-Política), a qual é aqui aplicada para compreender o pensamento político do Barão de HOLBACH. Deste modo, o leitor poderá encontrar no item 2. do presente texto segmentos que reproduzam trechos esparsos do item 3.4. da Tese de Doutorado (Duas Possíveis Qualidades das Leis: A Oposição entre a Organização JurídicoPolítica e a Jurídico-Teológico-Política), na medida em que, nos dois casos, se tratam de momentos de descrição do mesmo aparato conceitual de filosofia política utilizado para interpretar fenômenos distintos.

Assim, há entre os estudos um compartilhamento da chave de leitura aplicada para a interpretação de fenômenos. Todavia, em cada um deles o objeto estudado é distinto: na Tese, a construção histórica da Comunidade Europeia do Carvão e do Aço (CECA), enquanto que, aqui, o pensamento político do Barão de HOLBACH é foco privilegiado de estudos. Deste modo, apesar de a chave de leitura ser a mesma, os fenômenos estudados são distintos, razão pela qual o ineditismo das conclusões de um estudo não prejudica o do outro.

O leitor interessado pela distinção lefortiana entre Político e Teológico-Político - aqui rapidamente explicada em cerca de 5 páginas - poderá encontrar um aprofundamento sistematizado - em cerca de 30 páginas - das questões em torno dessa distinção naquele item 3.4. da Tese, ao qual remetemos a leitura.

\footnotetext{
${ }^{2}$ Nesse sentido, é interessante notar que esse "laço entre a legitimidade do poder e a legitimidade de um conflito que seria constitutivo da política" (Lefort 14, p. 264) aponta para o fato que do conflito surge a Política, sua necessidade e sua função, mediada pelo Poder; quando, no entanto, o conflito é instaurado para e pelo Poder, a Política instituída não visa à convivência dos Homens, apesar dos conflitos: muito pelo contrário, ela faz as vezes dele, ou melhor, a Política se instaura para e pelo Poder auto-interessado (o Poder faz o conflito, cria-o artificialmente, e torna-o dependente dela), impedindo a instauração do verdadeiro conflito, ou seja, da verdadeira Política e do verdadeiro Poder.

Esta reflexão sobre a artificialidade da Política e do Poder por meio da artificialidade do conflito instrumentalmente criado, apesar de interessante, não será objeto de apreciação pelo presente trabalho, a fim de não extrapolar os limites do mesmo. Fica registrado, aqui, o convite para futuras reflexões sobre o tema.

${ }^{3}$ Um Homem independente, mais forte, industrioso e feliz que os demais, portanto, não precisaria viver em sociedade. Essa situação seria impossível, segundo HOLBACH, por mais que imprudentes monarcas
} 
e soberanos separassem seus interesses de seus governados e se julgassem isolados deles: mesmo os governantes dependeriam de seus governados (Holbach 9, p. 9).

${ }^{4}$ Apesar de, em outro momento, o Barão de HOLBACH afirmar que "os reis não são os pais dos povos, [mas, sim, que] os povos são os pais dos Reis", por ser o consentimento da nação quem faz os Reis (Holbach 11, p. 17-8).

${ }^{5}$ Essa constatação do Barão de HOLBACH lhe permite concluir pela inafastabilidade entre Política e Moral (Holbach 11, p. 19), um tema recorrente da Filosofia Política Moderna desde a inauguração desta temática de forma mais bem definida por Nicolau MAQUIAVEL. 